\title{
Prior environmental characterization strategies for outfall systems
}

Alexandre Bach Trevisan / Ricardo Kazuo Furuya / Vanessa dos Santos

DOI 10.4322/dae.2016.010

\section{ABSTRACT}

Florianópolis is one of the most important touristic cities in the south region of Brazil. Six Wastewater Treatment Plants handles $50 \%$ of city sewage treated and disposal into fragile areas such as small rivers, mangroves and near shore locations into sheltered waters. To improve this situation two outfall systems are being planned.

Several aspects must be studied in the planning phase of a sewage project strategy through the construction of new treatment plants and disposal outfall. It always generates controversy with political, technical and social stakeholders. Local oceanographic and environmental knowledge are fundamental for the better understand about the outfall principles and phenomena.

This paper presents the strategies used to prior environmental characterization to support location and outfall technologies of two treated wastewater disposal systems. It summaries how a failure history turned to a wide data collection effort to support decision of design systems.

Keywords: environmental characterization, outfall, environmental assessment

\section{RESUMO}

Florianópolis é uma das mais importantes cidades turísticas do Sul do Brasil. Seis estações de tratamento recebem $50 \%$ do esgoto da cidade para tratamento e disposição final em áreas consideradas frágeis, tais como pequenos rios, manguezais e locais abrigados próximos à costa. Para melhorar esta situação dois emissários submarinos estão sendo planejados.

Diversos aspectos precisam ser estudados nestes empreendimentos devido às controvérsias entre os atores políticos, técnicos e sociais. Conhecimentos específicos sobre a oceanografia e ambiente local são fundamentais para um melhor entendimento sobre os princípios e fenômenos que cercam os emissários submarinos.

Este artigo apresenta as estratégias utilizadas para a caracterização prévia do ambiente para dar suporte à definição das alternativas técnicas e locacionais destes emissários. Ele resume como uma história de fracasso se tornou em um dos maiores esforços de coleta de dados para dar suporte a tomada de decisão sobre estes sistemas.

Palavras-chave: caracterização ambiental, emissário submarino, avaliação ambiental

Alexandre Trevisan: M.Sc. Chemical Engineering, Santa Catarina Federal University (UFSC), Brazil. Engineer at the Santa Catarina Water and Sanitation Company (CASAN). Rua Emilio Blum, 83, CEP 88020-010 Florianópolis - SC, Brazil. atrevisanacasan.com.br

Ricardo Kazuo Furuya: Biologist,Londrina State University (UEL), Brazil. Biologist at the Santa Catarina Water and Sanitation Company (CASAN). Vanessa dos Santos: Sanitation Engineering, Santa Catarina Federal University (UFSC), Brazil. Engineer at the Santa Catarina Water and Sanitation Company (CASAN). 


\section{INTRODUCTION}

Florianópolis, lies at the central coast of Santa Catarina State (figure 1), lapped by south Atlantic waters. The main island is separated by the continental part through a narrow channel of 500 meters approximately, which extension originates North and South Bay. (Diehl \& Horn Filho, 1996 apud CASAN and CB\&I, 2015).

The main island is presently served by six WWTP that collect and treat approximately $50 \%$ of sanitary wastewater produced in the city. Due to the rapid population growth and its fragile environment, full of small rivers, mangroves an bays, water pollution has been a big concern, important both from an ecological and social-economic point of view. Santa Catarina Water and Sanitation Company (CASAN) is planning two outfall systems in order to protect water quality on the beaches and in the fragile environments, avoiding wastewater disposal into the main bays on the west coast of the island.

Prior to outfall construction and because of the environmental requirements, it's necessary to undertake an environmental diagnostics of the influence area. At this stage, a good characterization represents a general concern and a great challenge, as it will support necessary steps in the development of these enterprises, from early outfall basic conception, project planning, design, construction, and operational monitoring.

According to Brazilian Environmental Council CONAMA resolution 001/86 (BRASIL, 1986), environmental diagnostics should create a deep knowledge of the area of influence of each project covering physical, biotic, social and economic aspects. Besides compiling existing information through literature review of available materials in the public domain, it is necessary to create and implementing a data collection plan that should last at least one completed hydrological year.

Data collection in the sea must be well planned due to significant effort and cost involved. Example of challenge to overcome during environmental campaigns such as the weather conditions in each season of the year, and equipment loss and degradation.

Earlier studies developed by CASAN and UNIVALI for environmental licensing process failed because of project problems, especially in the alternative election. This paper aims to present strategies adopted by CASAN to support environmental characterization prior to outfalls implementation in order to achieve goals within predetermined timetable and to retrofit the outfall design.

\section{GOALS}

Strategies adopted for prior environmental characterization of Santa Catarina Island shore are showed for the better understand of oceanographic, physical chemical and biological aspects, and their interrelation, for decision support of an outfall project in the study area.

\section{METHODOLOGY}

In this article are presented data of two case studies developed in the area, one on the North (CASAN and CB\&l, 2015) and other in the Southeast (CASAN and POLAR, 2016) portion of the island, with similar data acquisition approaches between 2013 and 2015 (table 1).

Water quality samples were collected at 3 depths (surface, half-deep and bottom) in 32 stations (figure 1). On the same stations sediment analysis and biological indicators were evaluated in an effort to identify relations between environmental compartments. 
For the oceanographic characterization, four Acoustic Doppler Current Profiles (ADCP) were installed (figure 1) on the seabed inside a structure with the transducer facing up (upward looking) in order to perform measurements of the vertical velocity profile with a pressure, temperature and salinity sensors as well. At the same time, in water quality campaigns, density profiles were investigated using a CTD profiler in each station.

Biological indicators like abundance, diversity, richness and equitability were calculated for different groups of the fauna and flora for each aquatic environmental, benthic and plankton, for the consolidated and unconsolidated subtracts (figure 2).

Table 1: Data acquisition period for the Norther (N) and Southeaster (S) outfall studies.

\begin{tabular}{|c|c|c|c|c|c|}
\hline & & 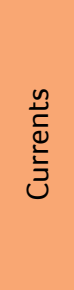 & 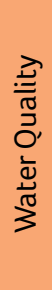 & 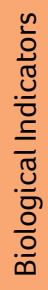 & 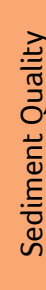 \\
\hline \multirow{4}{*}{2013} & Autumn & - & - & - & - \\
\hline & Winter & $S$ & $S$ & $\mathrm{~S}$ & $S$ \\
\hline & Spring & $S$ & $S$ & $S$ & $\mathrm{~S}$ \\
\hline & Summer & $S$ & $\mathrm{~S}$ & $S$ & $\mathrm{~S}$ \\
\hline \multirow{4}{*}{2014} & Autumn & $S$ & $\mathrm{~S}$ & $S$ & $S$ \\
\hline & Winter & - & - & - & - \\
\hline & Spring & $\mathrm{N}$ & $\mathrm{N}$ & $\mathrm{N}$ & $\mathrm{N}$ \\
\hline & Summer & $\mathrm{N}$ & $\mathrm{N}$ & $\mathrm{N}$ & $\mathrm{N}$ \\
\hline \multirow{4}{*}{2015} & Autumn & $\mathrm{N} / \mathrm{S}$ & $\mathrm{N}$ & $\mathrm{N}$ & $\mathrm{N}$ \\
\hline & Winter & $\mathrm{N}$ & $N$ & $N$ & $N$ \\
\hline & Spring & $\mathrm{N} / \mathrm{S}$ & $\mathrm{N}$ & $\mathrm{N}$ & $\mathrm{N}$ \\
\hline & Summer & S & $\mathrm{N}$ & $\mathrm{N}$ & $\mathrm{N}$ \\
\hline
\end{tabular}
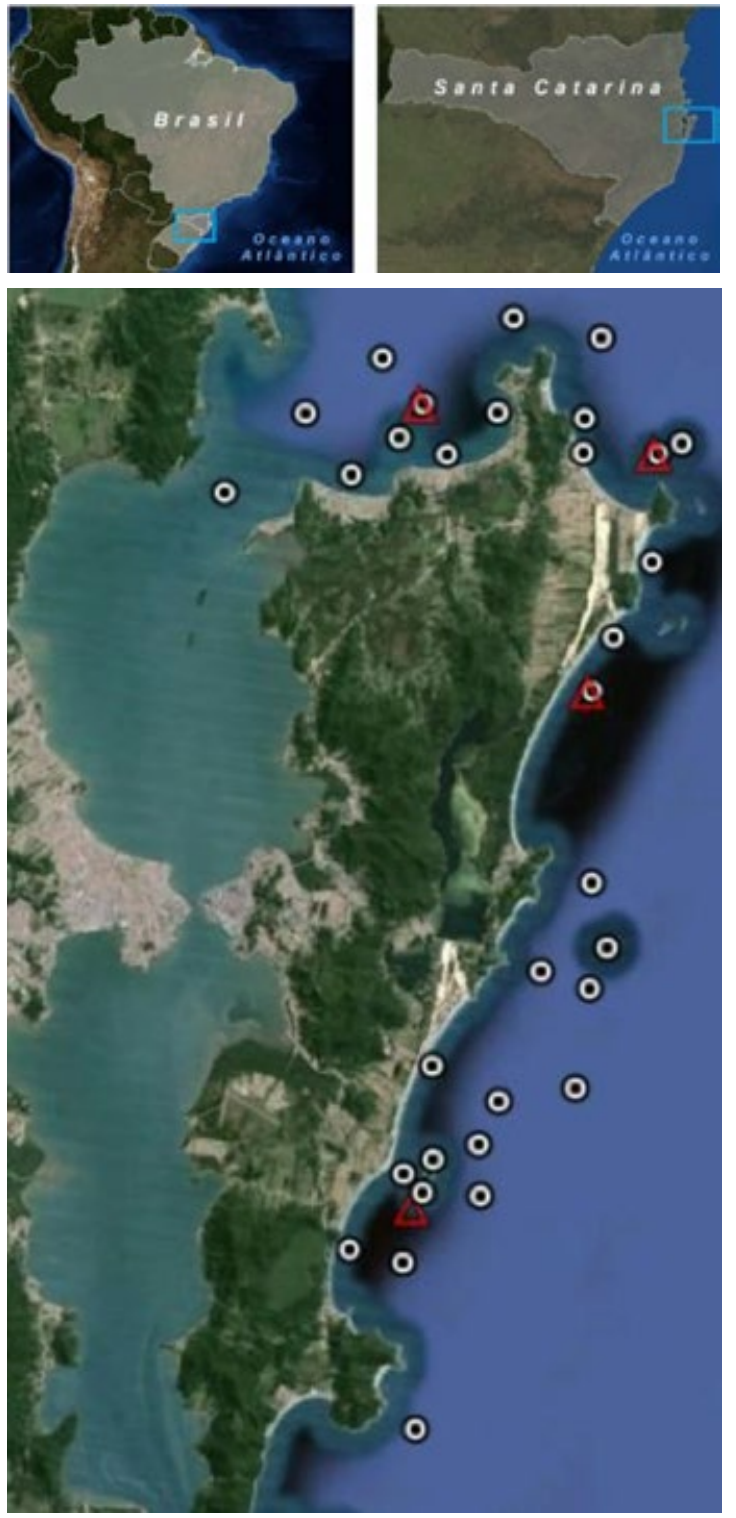

Figure 1: Study area - Santa Catarina Island. ADCP's (red triangle) and water quality (white points) stations locations.

Several water quality and sediments parameters were obtained, as showed in tables 2 and 3 , like nutrients, microorganisms, physicochemical, metals, emerging pollutants (poly Aromatic Hydrocarbon - PHAs) and Eco toxicological tests. 
Table 2: Analyzed parameters for water quality.

\begin{tabular}{|l|l|}
\hline \multirow{3}{*}{ Physicochemical } & Temperature,Salinity \\
\hline & Conductivity, pH \\
\hline Turbidity, Transparency \\
\hline Oil and greases, Surfactants \\
\hline Total Organic Carbon \\
\hline Chemical Oxygen Demand \\
\hline Sulfide, Ammonia \\
\hline Nitrite, Nitrate \\
\hline Total and Organic phosphorus \\
\hline Organic Phosphorous \\
\hline Dissolved solids \\
\hline Volatile solids \\
\hline Settleable solids \\
\hline Suspended solids \\
\hline Total solids \\
\hline Chlorophyll a \\
\hline Thermotolerant coliforms \\
\hline Organisms & E. coli \\
\hline Enterococcus \\
\hline Total coliforms \\
\hline Dissolved Aluminum, Cooper, Iron \\
\hline Total Arsenic, Cadmium, Lead, \\
Manganese, Mercury, Nickel, Zinc \\
\hline Total Phenol \\
\hline Metals & \begin{tabular}{l} 
IPAHs \\
\hline Eco toxicological test
\end{tabular} \\
\hline
\end{tabular}

On the sediments, besides the chemical characterization, a granulometric analysis was performed to identify the most adsorption susceptible areas.

Table 3: Analyzed parameters for sediment quality.

\begin{tabular}{|l|l|}
\hline \multirow{4}{*}{ Metals } & Arsenic, Cadmium, \\
\hline Chromium, Copper, \\
\hline Lead, Mercury, \\
\hline Nickel, Zinc. \\
\hline Total Organic Carbon \\
\hline Phosphorus \\
\hline Nitrogen \\
\hline Other & Sulfur \\
\hline Granulometry \\
\hline SPAHs \\
\hline Enterococcus \\
\hline
\end{tabular}

Table 4: Biological groups studied.

\begin{tabular}{|l|l|}
\hline \multirow{2}{*}{ Plankton } & Ichthyo \\
\hline Zoo \\
\hline Benthic & Phyto \\
\hline \multirow{2}{*}{ Other Groups } & Macrophyto \\
\hline Demersal fauna \\
\hline Marine mammals \\
\hline Chelonia \\
\hline
\end{tabular}

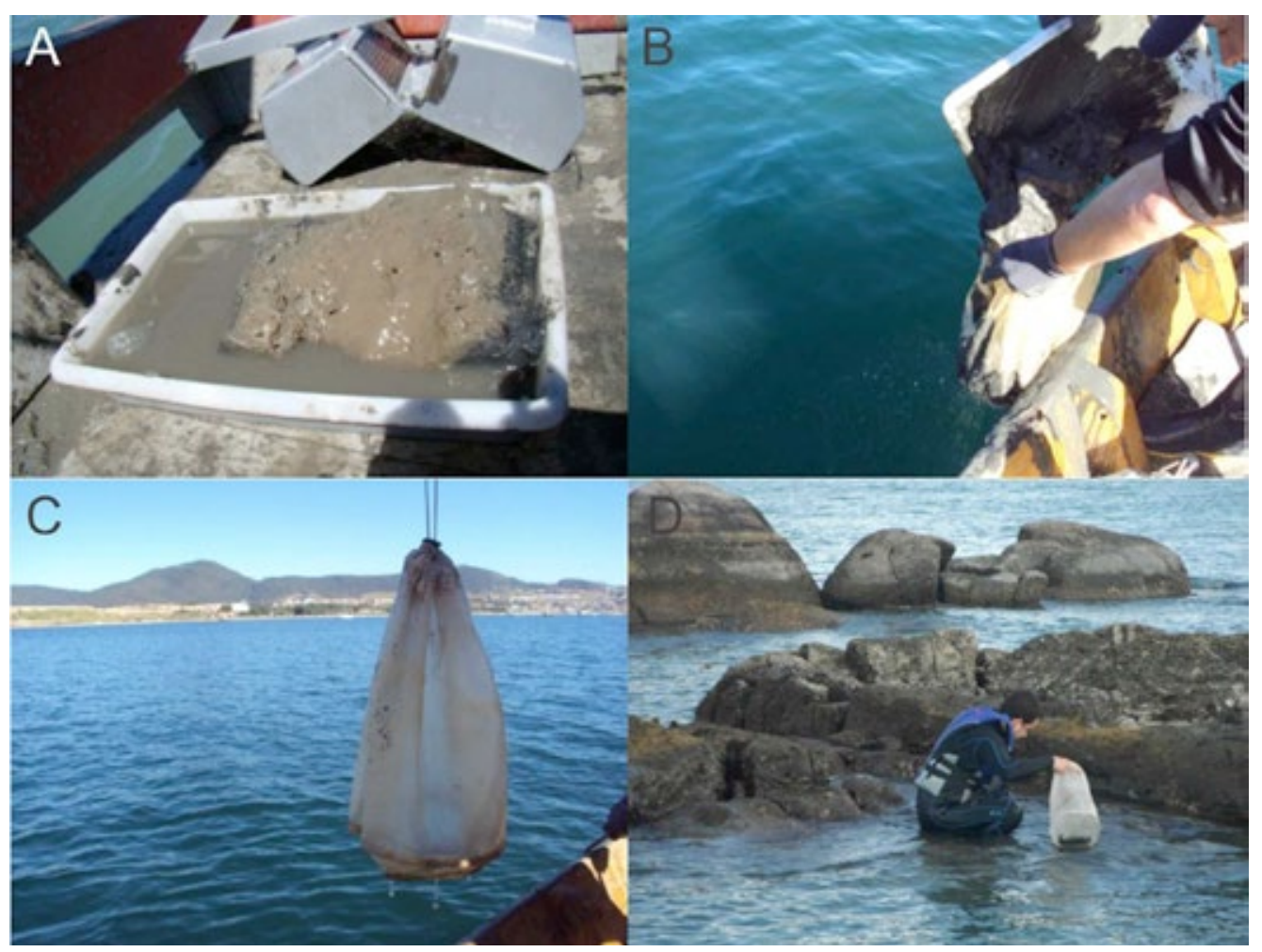

Figure 2: Biological collect for the different substracts and groups ( $A$ and $B$ - Benthic macro fauna, $C$ - Phytoplankton and $D$ - Benthic macro fauna and macro phytobenthic in a rocky coast). (CASANand POLAR, 2016) 


\section{RESULTS}

Both studies bring up about 30,000 water quality data, 2,000 sediment data and 640 biological samples between 2013 and 2015, in one the major data collection campaigns realized in the region.

Furthermore, this amount of information was also converted into thematic maps for the trial and identification of patterns and relation between parameters, compartments and stations. Each campaign and depth was presented in a map, as shown on figures 3 and 4 , in order to evaluate seasonal patterns and to look for local phenomena related in the literature, such as upwelling (CAMPOS et al, 1995 and CARVALHO et al, 1998). Special attention was given for temperature, salinity and nutrients, due to the upwelling reports and its implications for the wastewater plume.

On sediments, the same graphical approach was used in order to make data interpretation easier. It was possible to identify that more exposed areas had sand prevalence and clay enrichment, which was observed closed to the protected waters of the northern bay (figure 5).

Oceanographic time series measurements were treated to remove peaks and other deviation occurred during the data collect procedures, such as pitch and roll.

Filtered data was submitted to a frequency of occurrence verification and water level groups summarize data for different layers (surface, half-deep and bottom) and different shore orientation ( $x$ cross-shore and y - long shore) (figure 6). Velocities profiles along campaigns were also generated observing total currents, South-North and NorthSouth orientation. Different approaches were made to analyze data such as polar diagrams, distribution of vertical profiles, magnitudes histograms and accumulated distribution (figures 6 and 7).
The biological samples were submitted to an ecological approach. Descriptors and indicators were combined at different stations and groups, such as phytoplankton, zooplankton and benthonic organisms. The studies performed the Shannon-Weaver and Pielou index in complement to abundance and richness analysis, like the example showed in figure 8.

\section{DISCUSSION}

Previous studies involving environmental data collection were developed by CASAN at the same region few years ago to support first outfall projects. According to CARVALHO et al (2013) time series of wind, water levels current and temperature profiles were acquired over a period of 31 consecutive days in order to determine the best location for the diffusers. Due to the short monitoring period, the environmental agency considered not sufficient to afford knowledge of the local oceanographic aspects. The intention to validate biological data collected from one monitoring point to another, in order to avoid other campaign effort failed, even due to their spatial proximity. These justified a new primary data collection for the whole area for a better and complete environmental characterization, into a new licensing process. These studies were developed into this methodology.

To prevent loss of equipment and ensure the data quality, it was provided one campaign every 45 days for ADCP maintenance and data collection. First campaign showed problems with lost or drag of 3 ADCPs. This approach permitted an exchange location to near protected areas and ensure the data acquisition for the next measurements.

Large majority of sediment data was detected above limits of Brazil legislation for dredged material (BRASIL, 2012), with almost all data even below the method detection limits, showing that the area is preserved for anthropic interference. For water quality it was observed the same characteristic with few parameters up to the regula- 
tion patterns (BRASIL, 2005). Additional interesting information is that sediment granulometric composition had variability over the seasons and over the different exposure areas, like bays and open sea, and bathymetric profiles (figure 5).

CARVALHO et al. (1998) observed two distinct oceanographic seasonal patterns influenced by the wind in this region. During spring and summer the water columns was stratified and upwelling and doweling events occur according to the northern and southern winds. During autumn and winter the water column was homogeneous because of doweling or advection of modified subantartic water into the area. The upwelling of Central Southern Atlantic Waters (ACAS) was detected in the northern study during spring and summer as showed in figure 9. CTD data (figure 10) showed the same upwelling pattern with additional temperature and salinity stratification on the spring of 2013 (green) and in summer of 2014 (cyan), in according with the author.

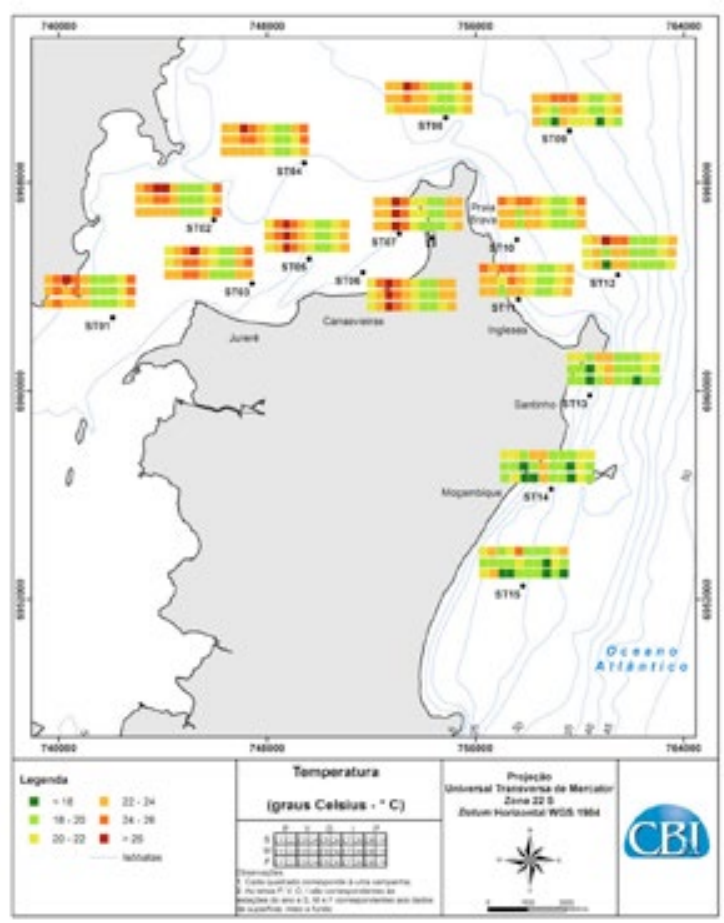

Figure 3: Water quality (Temperature) maps developed in the North Outfall study. (CASAN and CB\&I 2015

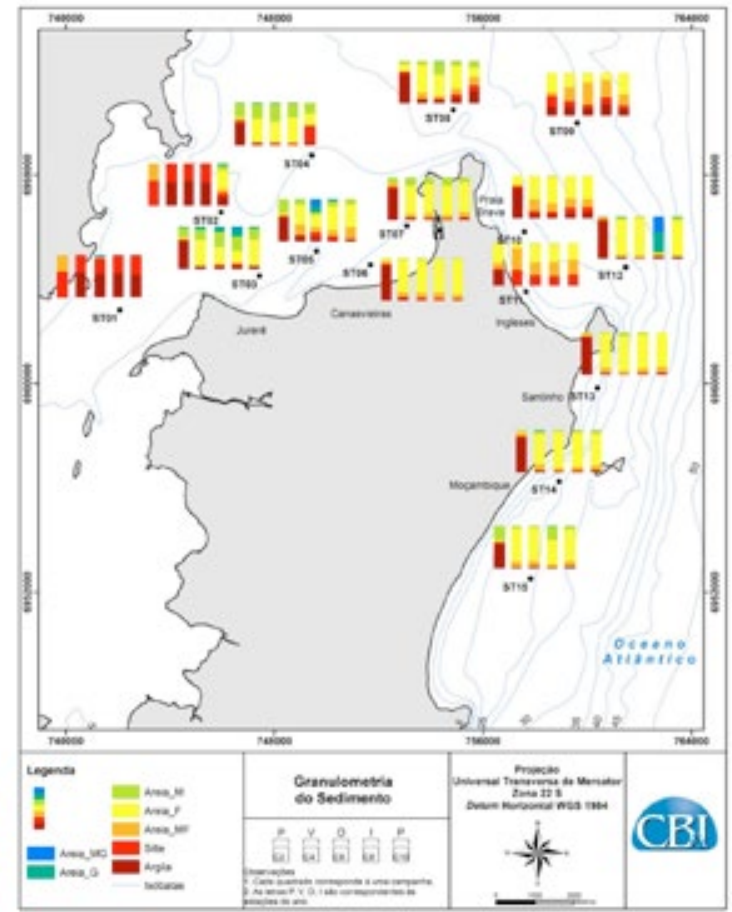

Figure 4: Example of water quality (Temperature) maps developed in the Southeastern Outfall study. (CASAN and POLAR, 2015)
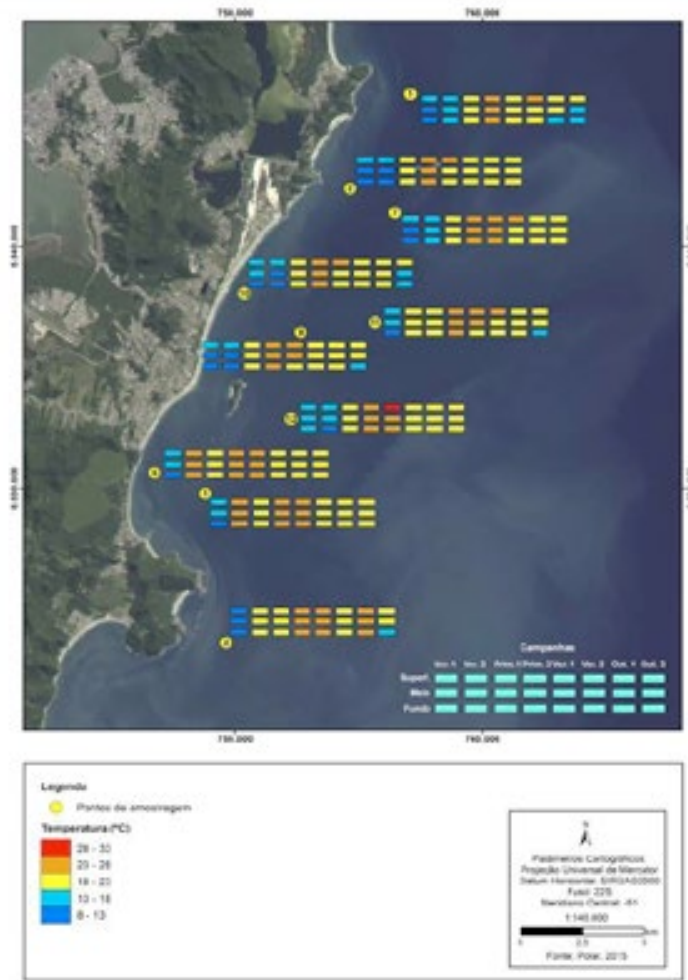

Figure 5: Example of sediment classification distribution on the Northern Outfall study. (CASAN and CB\&I, 2015) 

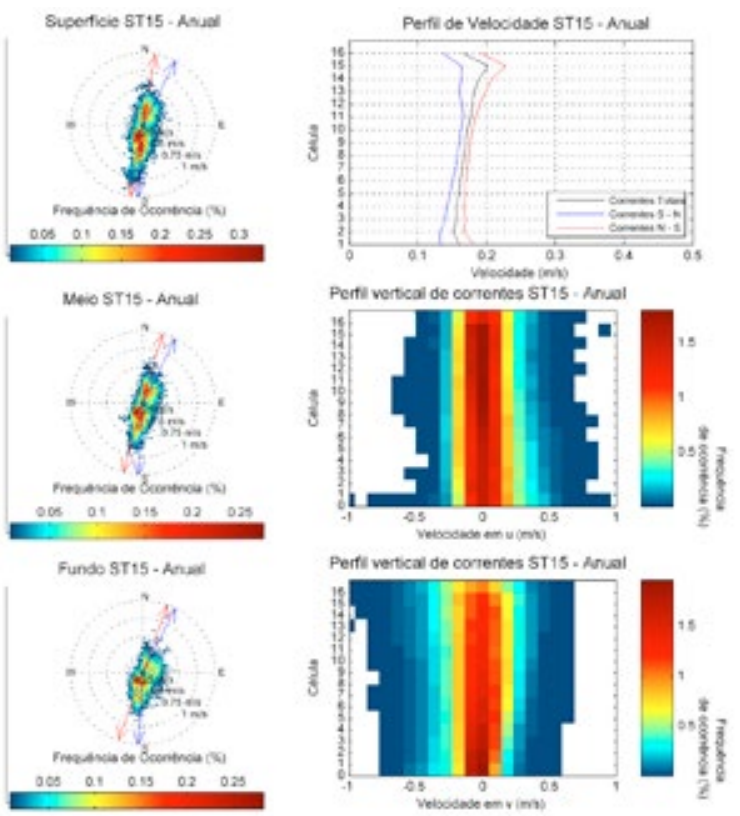

Figure 6: Example of oceanographic data analysis with polar distribution and vertical profiles. (CASAN and

CB\&l, 2015)

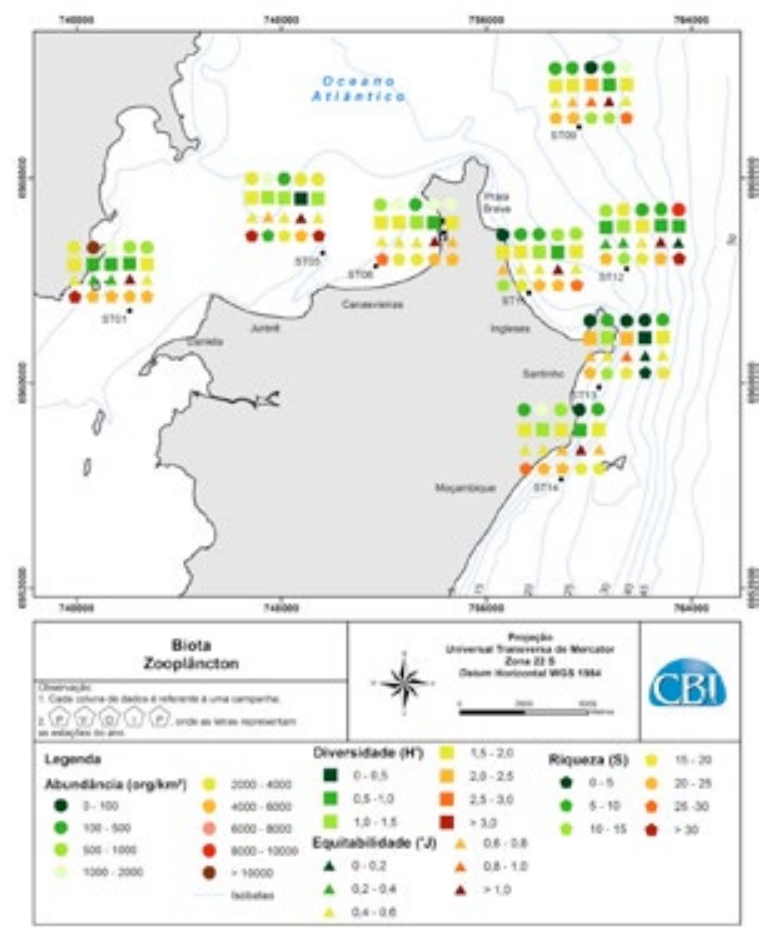

Figure 7: Example of oceanographic data analysis with histogram of magnitude and accumulative distribution. (CASAN and CB\&I, 2015)
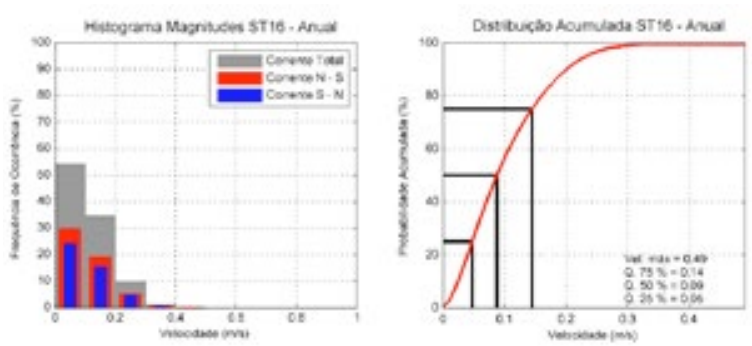

Figure 8: Example of biological indicators distribution for de Northern Outfall study. (CASAN and CB\&I, 2015)

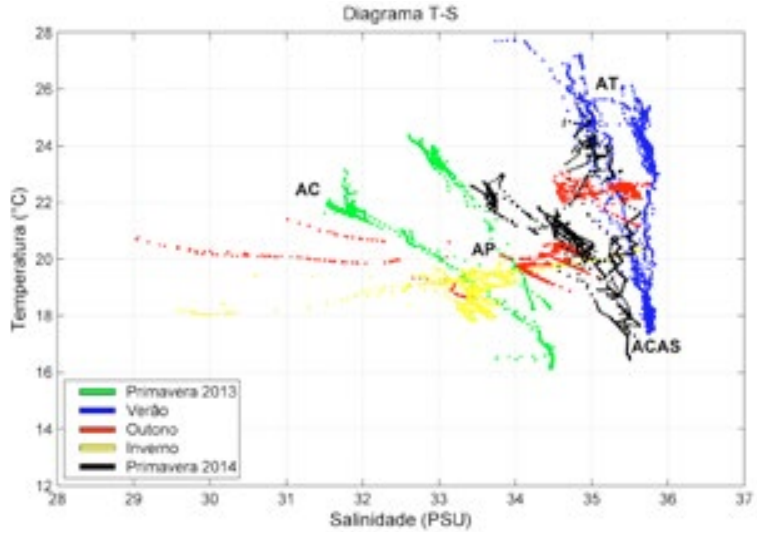

Figure 9: Analysis of water masses occurrence in a Temperature versus Salinity diagram. (CASAN and CB\&I, 2015)

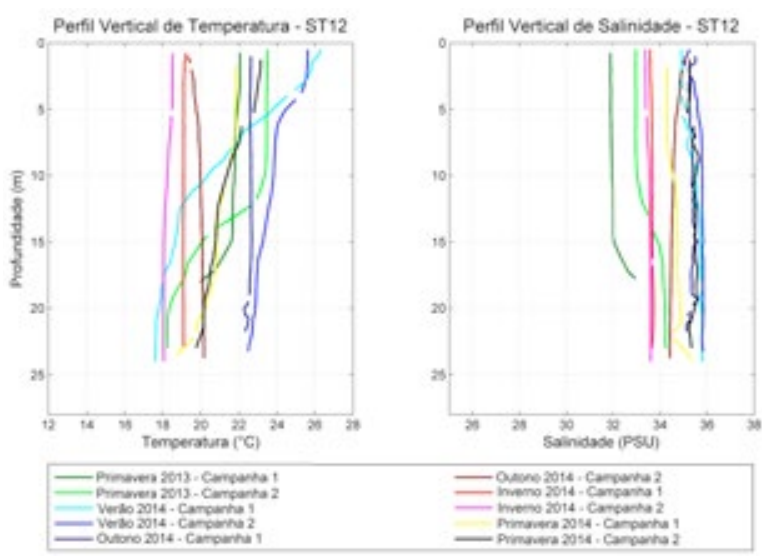

Figure 10: CTD profiles for one station in the northern study.Temperature on the left and salinity on the right.

(CASAN and CB\&l, 2015) 
FALKENBERG et al (2016) and BARLETTA et al (2016) also discussed the oceanographic data of the northern outfall with more details showing that even in a small region the local geomorphology differences plays an important role defining the major forces that act in each site. Tides look the most relevant forcing phenomena on the bay influenced areas. Waves and meteorological aspects, such as cold fronts, performed the most significant influence on the more exposure areas on the east.

Taking into account the regular characteristics of urban sewage and treated wastewater, it is important to evaluate the natural background of nutrients such as total organic carbon, nitrogen and phosphorous forms. The study showed a previous background carbon (figure 11) observed sometimes in the whole region. Probably this phenomenon is related to the different water masses, and oceanographic and meteorological interactions. The same background pattern was observed in the southern region with nitrogen forms.

Shannon's diversity index ( $\left.H^{\prime}\right)$ scored the highest values during winter and spring when climate conditions, physical environment and also local environmental factors favored richness values (S). In the Northern study, autumn had the highest values of Pielou (J) index of equability where there was a better distribution in the number of organisms between species without significant dominance. However, in the Southeast study, highest Pielou values were obtained in summer period.

Taxonomic richness is strongly correlated with climate and environmental conditions, both for northeast and south part of the island.

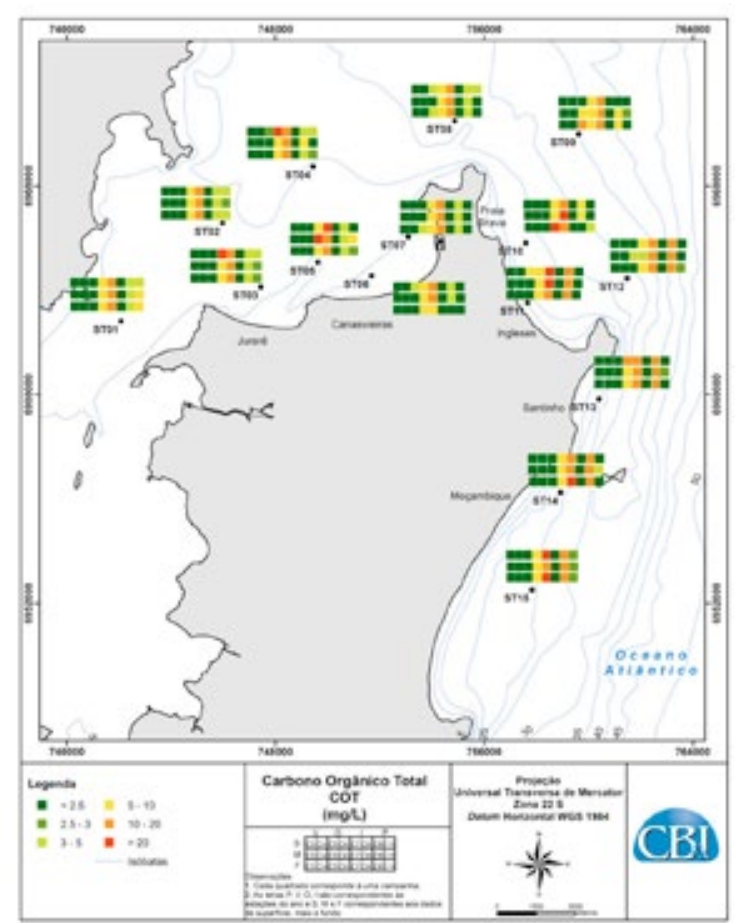

Figure 11: Total Organic Carbon distribution over northern shore. (CASANand CB\&I, 2015)

\section{CONCLUSION}

Practical experience shows that in public discussion of an environmental assessment, divergences are about few key subjects that attract public interest (SANCHEZ, 2011). Most of these talks are about locational characteristics, following the not in my backyard feeling. In Brazil, public meetings and discussion take part into environmental licensing process. Before these meetings, a complete diagnosis of the biological, physical and social aspects must be presented for a complete evaluation of the environmental authority.

Previous characterizations is a fundamental tool for the decision making process of an outfall system. Several social aspects must be taking into 
account, but the most important issue is show to the stakeholders and to the scientific and technical community that the best efforts are being made in the planning phase to make sure that the outfall will not damage the environmental, especially the beaches and other social uses.

Nutrients parameters are especially important. Combined with circulation data they helped to detect upwelling events. These background data will help further studies to understand the real impact of the outfall operation.

Taking into account that during outfall operation, water quality, sediment sand biological indicators will be monitored, it is important to pay attention in some aspects like methodology detection limits of water quality and sediment parameters. These limits cannot be closer to regulators standards. At least one order of magnitude lower that Brazilian regulation standards.

Other studies were performed next to these study area by different institutions covering all around the island, but this efforts are not integrated. This increase the need of a public and open database to permit frequent partnership between institutions and support discuss with stakeholders to improve projects and minimize social restrictions and doubts about outfall solutions.

\section{ACKNOWLEDGEMENT}

Thanks to CASAN (Companhia Catarinense de Águas e Saneamento), CB\&l (Chicago Bridge \& Iron Company) and Polar Engenharia e Meio Ambiente staff for the effort dedicated to this studies as well as UNIVALI for the first investigations and support.

\section{REFERENCES}

BARLETTA, R., RIBEIRO, P., FALKENBERG, A., MARANHÃO, M., FRANKLIN, L., BENEDET, L., DE LARA, P., TREVISAN, A., DOS SANTOS, V., BLENINGER, T., Physical Oceanographic Measurements to Support the Outfall System Design in the North of Santa Catarina Island, Brazil, Proc. Intl. Symp. On Outfall Systems, Ottawa, Canada, 10-13.05.2016

BRASIL. Ministério Do Meio Ambiente, Conselho Nacional De Meio Ambiente. Resolução CONAMA nº 001, de 23 de janeiro de 1986 - In: Resoluções, 1986.

BRASIL. Ministério Do Meio Ambiente, Conselho Nacional De Meio Ambiente. Resolução CONAMA n ${ }^{357}$, de 17 de março de 2005 - In: Resoluções, 2005.

BRASIL. Ministério Do Meio Ambiente, Conselho Nacional De Meio Ambiente. Resolução CONAMA n⿳0 454, de 01 de novembro de 2012 - In: Resoluções, 2012.

CAMPOS, E. J. D.; GONÇALVES, J. E. \& IKEDA, Y. Water mass characteristics and geostrophic circulation in the South Brazil Bight - Summer of 1991. Journal of Geophysical Research, 100 (C9):18537-18550. 1995.

CARVALHO, J.L.B.; SCHETTINI, C.A.F. \& T.M. RIBAS.Termohaline Structure of Santa Catarina North Coast. Notas Técnicas da FACIMAR, 2: 181-197, 1998.

CARVALHO, J.L.B.; TREVISAN, A.; SANTOS, V.; FRANKLIN-SILVA, L.; ALVES JR, L.A. Modeling the Praia dos Ingleses submarine outfall, Florianópolis, Santa Catarina, Brazil. Water Science and Technology, v.67,p.1832, 2013.

CASAN, CB\&l, Relatório de Diagnóstico Oceanográfico e Ambiental, DO-7- Technical report. Estudo Oceanográfico e Concepção de Alternativas Locacionais e Tecnológicas para a Disposição Oceânica dos Efluentes Tratados- Norte da llha de Santa Catarina. 2015.

CASAN, POLAR AMBIENTAL. Relatório de Diagnóstico Ambiental Consolidado A7 - Technical Report. EIA/RIMA do sistema de disposição oceânica dos efluentes tratados no sistema integrado de esgotamento sanitário - sul de Florianópolis: estudo oceanográfico consolidado. Florianópolis (SC); 2016.

FALKENBERG, A., BARLETTA, R., FRANKLIN, L., RIBEIRO, P., DE LARA, P., BLENINGER, T., TREVISAN, A., DOS SANTOS, V., Optimizing Outfall System Configurations using Decision Support and Numerical Models. Case Study of Santa Catarina Island, Brazil, Proc. Intl. Symp. On Outfall Systems, Ottawa, Canada, 1013.05.2016

SANCHÉZ,L. E. Avaliação de impacto ambiental: conceitos e métodos. São Paulo: Oficina de textos, 2011. 495 p. 2011. 